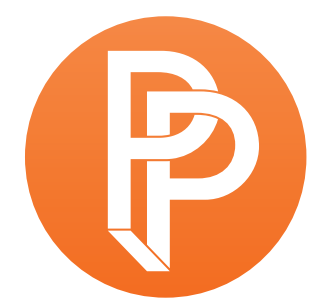

PERFORMANCE

PHILOSOPHY

\title{
MAKING NEW LAND: AN INTERTIDAL AESTHETICS
}

\author{
THOMASPAUSZ ICELAND UNIVERSITY OF THE ARTS
}
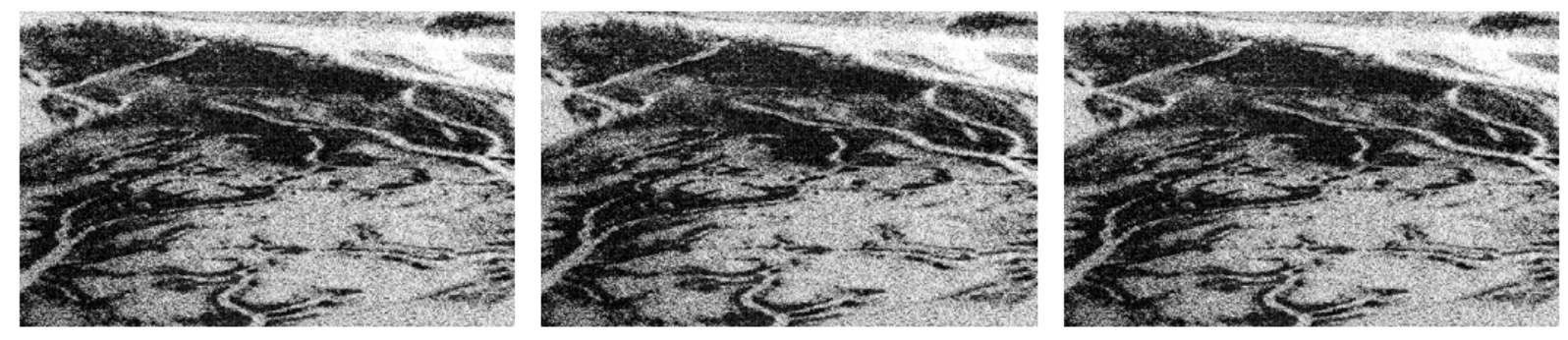

Images in collaboration with Jan van der Kleijn

"Except for the beaches, which always remain the same"

- Agnes Varda

\section{Sea for Space}

Little attention had been given so far to the report of the Sea for Space expedition on Mars. No doubt the aura of mystery and pseudo-science around the Oceanus Borealis hypothesis contributed to this neglect. To this day, any mention of the existence of an archaic ocean on Mars raises unanimous skepticism in the scientific community. However, in the wake of the disturbingly wet-looking images emitted from the northern plains of the Red Planet that summer, every former report related to Oceanus Borealis had to be re-examined. My job was to investigate the findings of the Sea for Space group of astrobotanists, who had been stationed on these faraway shores for many years. I knew their mission had been a historical scientific fiasco. It ended in a sad mess, with 
several researchers disappearing and the rest being forbidden from practicing any scientific activity. But I had gotten quite a reputation for my talent at finding gold in the most glitchy archives at the Department. Granular data was my territory.

Sea for Space was an enigmatic group. As the legend goes, it consisted of amateur ocean biologists from Iceland and a few expatriated botanists from France. Even before the last stretches of oceans had dried up on Earth, ocean studies had become a minor discipline in the shadow of the more prosperous astrogeology. To put it plainly, ocean studies was seen as a desperate treasure hunt to discover "life" amongst fossils of desiccated seaweed, crumbling coral reefs, and sedimented plastic waste.

The intertidal marshes, these former wetlands between the sea and the secondary dunes, had slowly recessed with the water from all corners of the globe, leaving the mudflats to dry up like a giant crème brûlée. Before long the oceans had grown into a gigantic desert around stale pools of mud.

Intertidal melancholia had become a full-blown artistic and literary genre in those days. Poets and artists competed in rewriting the mythology of thriving and idyllic coasts, evoking magical sea monsters and the beauty of sea flora and fauna shimmering under the waves. I am a collector of these strange lamentations. I find them a soothing treat after a day of dry data-crunching at the Department. For those unaware of this artistic niche, I share here below some fragments of my personal collection of artworks and my favorite text. I hope it will come to light how related this all is to my inquiry into Sea for Space and the Oceanus Borealis mystery.

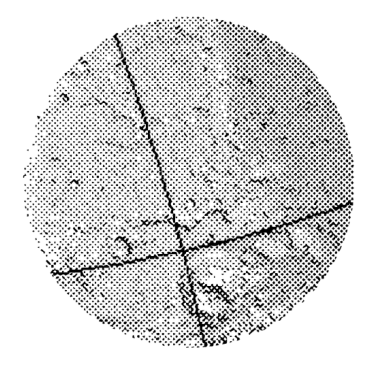

No one better than 20th-century French writer Michel Tournier had captured the harsh beauty of the intertidal zone. I often cry when I read these pages of Tournier's novel Gemini, where the author describes the childhood of two brothers on the coast of Brittany: 
What drew me so powerfully to the wet beach on the nights of neap tides was a kind of silent cry of helpless desolation that rose from the uncovered seabed. The things that the ebb lays bare weep for the flood tide. The mighty glaucous mass fleeing towards the horizon has left exposed this living flesh, complex and fragile, which fears assault, profanation, scouring and probing; this batrachian body with its blistered, glandulous, warty skin, thick with papillae, with suckers and tentacles, shrinks before the nameless horror that is the absence of the saline medium, emptiness, and wind. The thirsty foreshore, bared by the ebb, weeps for the vanished sea with all its streams, all its oozing pools, all its brine-swollen weeds, all its foam-capped mucosities. It is one vast lamentation, the weeping of the suffering shore, dying beneath the direct light of the sun with its terrible threat of drying out, unable to bear its rays except when broken, cushioned, and fragmented by the liquid, prismatic depth. (Tournier 1981, 129)

In the words of 21st-century philosopher Emanuele Coccia, the landscape of the intertidal wetlands, where "life is challenged by life itself," evokes a specific feeling:

The great Melancholy, which strikes us when our preconception of a peaceful, harmonious 'Nature' is challenged. (Coccia and Despret 2018)

When beholding the marshes, where everything is relentlessly submerged, broken down, and digested, we witness with Tournier and Coccia that "any ecosystem is by nature post-apocalyptic and is built upon the ruins of prior ecosystems." This brutal intertidal drama started with the slow selective death of anaerobic species during the transformation from Sea to Land Life, and it was amplified by the invasion of human detritus into the fabric of the Oceans in the 20th Century followed by the excesses of Shore and Sea mining in the 21st.

For the same reasons, previous generations were both fascinated and revolted by the intertidal life forms, the tentacular fauna and flora so well described by Tournier and Rachel Carson, which belonged to both wet and dry ontologies. The lurking mudfish, the urchin buried in the wet sand, the octopus camouflaged in the seabed, the plastic-eating worms. In our obsession with reaching other worlds and planets after the oceans vanished, we might have become more akin to these glaucous hybrids than we would like to admit. Interrogating the interplanetary condition, 21 stCentury author Benjamin Bratton described the cosmonaut not as a mighty pioneer fronting a mythical quest but, rather, as a fragile creature taken out of its ecosystem and hiding in multiple technological shells: the helmet, the cabin, the space station (Bratton 2019). Uncertainties and fears, which had a home in the intertidal zone, have not disappeared: they have diffracted out into the cosmos, all the way to Oceanus Borealis.

We can also find echoes of intertidal melancholia in the humorous and macabre imagery of Eileen Agar. Agar was a unique Surrealist artist who explored the entanglement of bodies on the shores through a practice of collage. Her skull with shells and bouillabaisse hat, both resembling the process of natural biofouling that used to take over boats and sea infrastructures, have a strangely hypnotizing beauty. 


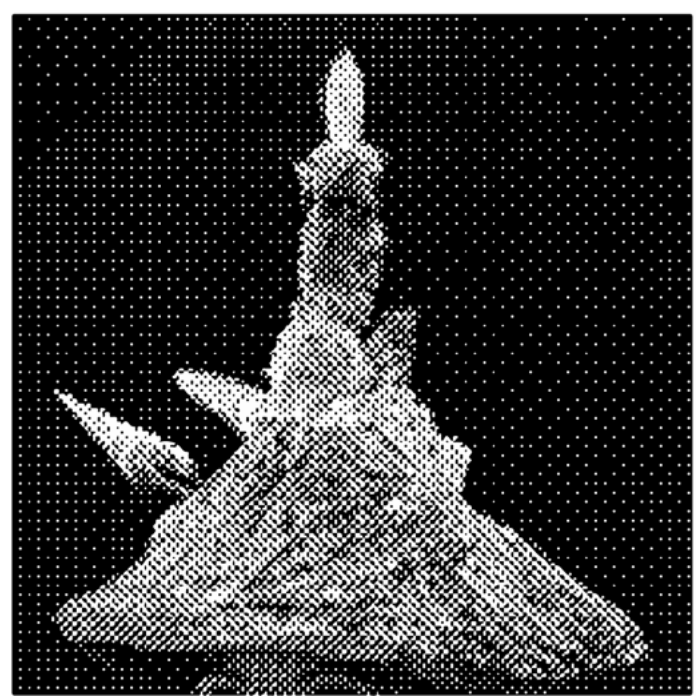

The intertidal marshes and the sandy coasts were indeed highly sensible zones in the context of climate change in the early 21st century, as testified by the ubiquitous ruins of artificial seawalls and flood barriers that can still be excavated. According to a Coastal Problems study, more than $70 \%$ of sandy coastlines worldwide were suffering from erosion for decades before the Great Ocean Rise.

The factors causing this erosion were multiple. They ranged from direct human-induced damage such as sand mining and the removal of kelp and dune grass, to more complex anthropogenic processes disturbing the normal circulation of sediments and accelerating the rising of sea levels. This mass erosion of sandy beaches was perceived as a threat to populations depending on land and soil for survival. The industrial and human-centered answer to this threat was swift and brutal: the systematic deployment of a range of hard landscaping architectural forms, from seawalls, jetties, and groynes to barrier islands along all the coasts. A new industry isolating land from sea flourished. Coastal plant forests were uprooted to make way for long concrete emergency dikes; salicornia, dunegrass, beach heather, and goldenrod plant communities were set on fire or shredded without mercy to fuel interplanetary transport. Isolated from their ecosystems and symbiotic companions, the handful of bushes that were spared in this ruthless hard landscaping process of the shores slowly desiccated when the oceans recessed a few years later.

As remarked by the author of Coastal Problems (1995), protecting the land with hard barriers went hand in hand with destroying the ecosystems of the beaches. A closer look at these short-sighted solutions revealed that in the long term, they participated in the same problem by further disturbing the circulation of sediment that regulated the geomorphology of coastlines. Like in a Borgesian short story, coastal communities soon had to build new seawalls to protect the old eroding seawalls, in an endless race against the ocean "locking coastal managers into a neverending program of artificial shorelines maintenance and control" (Viles and Spencer 1995, 350). 


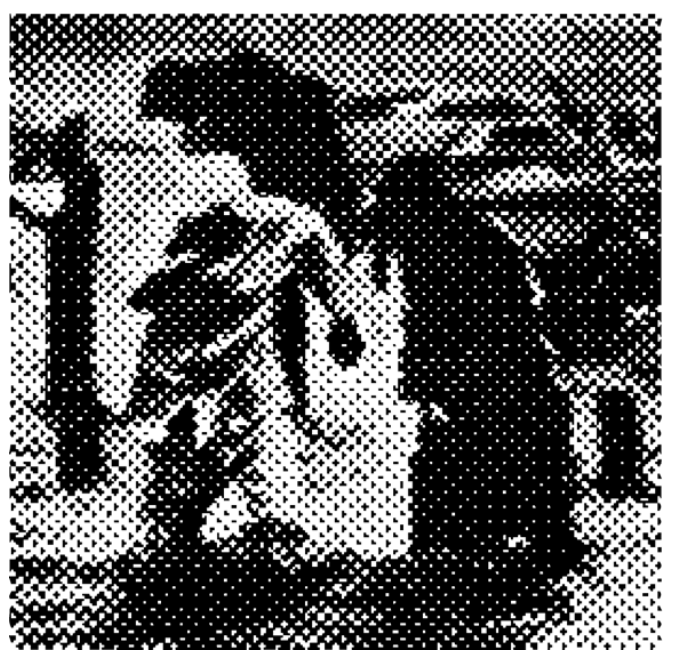

Salicornia

In the last decade of the Blue Marble Era, the Sea for Space gang was roaming the gloomy mudflats between Iceland and Greenland. By default, they took to the study of the last recorded specimens of a plant called Salicornia europaea. These archaic shrubs used to cover the sand dunes of many shores, forming a lush miniature salty jungle in association with other pioneer plants and microorganisms. Salicornia was one of the first plants to effectuate the passage from sea to land life, from anaerobic to aerobic life. Its delicate tubular morphology made of "true leaves" was a complex bio factory of desalination. As seawater traveled from the root cells through the epidermis of the plant, salt was rejected on the outside and freshwater channeled to the top.

Salicornia had been known to humans under many names: samphire, glasswort, Mother of Glass, Al' kali, sea asparagus, Protector of Sailors, and more. This semantic variety did not only reflect the many subspecies of the genus Salicornia populating the beaches. It was also a testimony to the thousands of uses this plant had been put to in the history of human industries: from soap-making in the ancient Middle East to glassmaking in medieval Venice; from salt-harvesting in Brittany to distilling biofuel for space travels in South America in the late 20th century. When botany was still thriving, some studies were even conducted about mass cultivation of the plant in carbon capture fields, as their carbon metabolizing rate was higher than the rate of most trees. A true ally to humankind, Salicornia had survived world wars and the recent Era of Ecological Disasters.

Surprisingly, a Sea for Space paleobotanist claimed to have spotted some lone specimens of Salicornia plants surviving in one of the poor districts that could not afford to pay for maintenance of the flood protection dikes. There, "a number of projects were tearing down (old) seawalls and sacrificing land to develop into salt marshes as a buffer against wild seas" (Simons 2016). These natural buffers were seen as cheaper options for areas that had no real economic value. 
These unexploited terrains-vague had become ad-hoc nature reserves, "third landscapes" (Clément 2005), where water and hardy species lingered a few years longer.

How could salicornia individuals survive the extreme rise and fall of sea waters and adapt to both dry and wet extreme conditions? Even the mythologically hardcore mudfish and the resilient urchins had turned into dust by then.

Sea for Space published a thorough study on this salicornia phenomenon entitled Making New Land: An Intertidal Aesthetics. This speculative botanical and geological publication made quite an impact on me when I was a young terraforming student. It was first and foremost an activist book, where the authors exhorted coastal communities to stop building higher hard dikes and artificial flood barriers and to start replanting salicornia everywhere instead. Their main argument was that "this unassuming plant, almost prehistoric-looking, with its tiny leaves and small thin flowers [...] is our first line of defense against storms and rising sea levels that batter the coastline and lead to serious erosion"(Simons 2016, 1).

Can a mundane shrub have been our defense against global erosion? Could the planting of an intertidal forest have changed the course of events? According to the authors, salicornia "makes its own land" by gathering debris of shell, sand, and organic matter around its roots. This "dissolved organic matter" becomes a firmer soil through further symbiotic bacterial transformation. This soil can then be colonized by the secondary plants, whose roots consolidated the dunes and formed the lost silhouette of the old shorelines. In a fascinating gesture of biological self-sacrifice, salicornia "creates the conditions for its own annihilation"(Mabey 2015, 160).

To think that the shape of continents could be designed and protected by plant-bacteria associations was a very controversial theory. The volume Making New Land was filled with models and obscure diagrams of what is described as "plant architecture" to support the author's ideology.

Unthinkable today, but these theories of plant agency made a lot of us dream at the time.

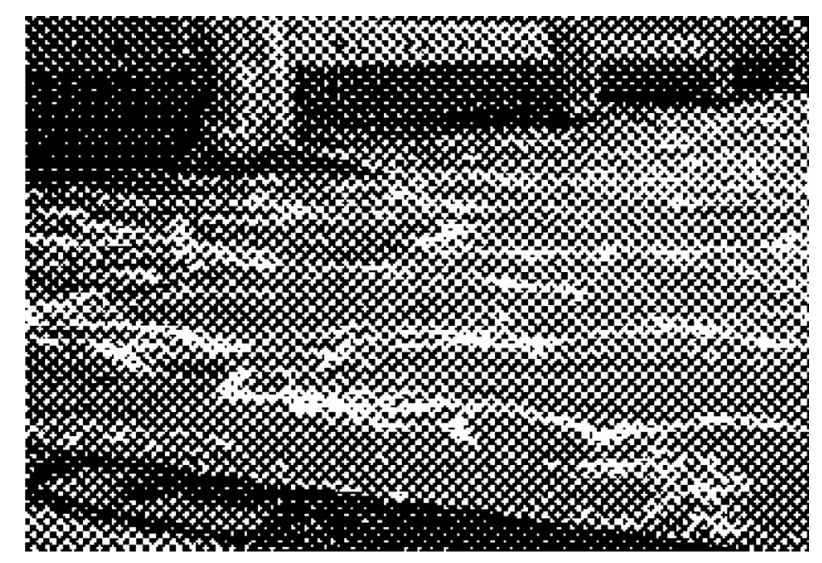




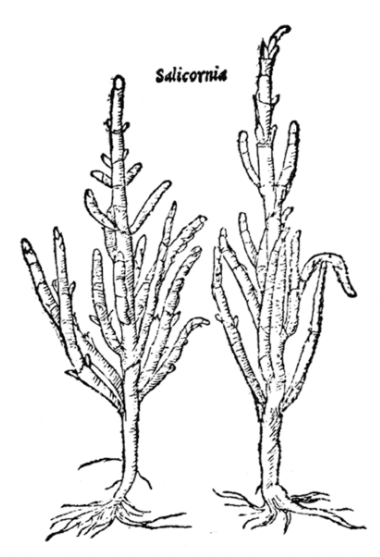

The Making New Land study referenced a forbidden book entitled Designing with Nature by lan McHarg. This older pamphlet advocated for a deeper understanding of natural processes such as the complex formation of dunes and shorelines as a source of knowledge for landscaping and terraforming. McHarg's famous exhortation "Man must become the steward of the Biosphere" has often been taken out of context by anti-naturalists. The end of the sentence was "To do so, he must design with nature" (McHarg, 1969, 5).

In McHarg's holistic environmental philosophy, a careful study of natural processes could give us some precious clues on how to deal artificially with landscape and climate processes. From a survey of humble dune vegetation, for example, McHarg extracted some precise indications on how to construct a series of complementary dikes, which would act as filters rather than walls. With McHarg, Sea for Space defended an "aesthetic of membranes, porosity, fluidity, toxicity, filtering, convergence, osmosis, transfer, exchange" (Sea for Space 2014, 4). For them, "a body or a country that builds hermetic walls around itself is already a dead body" (Sea for Space 2064, 6).

A haunting quote from the chapter "Sea and Survival" in McHarg's book was reproduced on the back cover of Making New Land:

\section{Thou shalt not walk on the dune grass. \\ Thou shalt not lower the groundwater below the critical level. \\ Thou shalt not interrupt the littoral drift.}

In the most infamous final argument, the authors of Making New Land go so far as to draw some links between these holistic landscape studies and ancient traditions such as "shore shamanism" in Canada and France: "Shamans of the Shores," they write, "recognized intertidal spaces as liminal spaces, ecological limits where civilizations are made and unmade" (Sea for Space 2064, 10). 
Our scanning drones still find ritual shamanistic artifacts buried in the desertic mudflats. Sculpted puffin heads, for example, were a frequent feature, because of the half-fish, half-bird nature of puffins. Other favorites were carved reliefs representing the devilish-looking octopus. Making New Land was a unique prophetic mix of nature observation, indigenous knowledge, and exhortation to technological disobedience. It might have been the last attempt at a "holistic thinking" of the environment. The book was censored immediately.

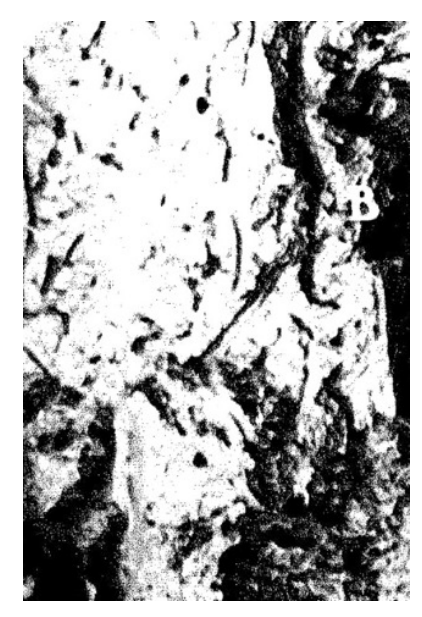

The Intertidal shellfish rose and flower-headed zoophytes from a strange age of naked, plant less lands evolved around the sweeping fishless seas that had no names. Within and beneath this incomprehensible, predestined march of a million summers and faded pictures, the fish, our ancestors, rushed through the waters of later worlds. The first bees, flying over colossal forests whose feet stood in slime, living in pairs and small families, evaded the great spiders and centipedes. Dragonflies with two-foot wings nested in the undergrowth at the edge of a limitless sea. Continents started to separate. (Buxton 2006, 178) 


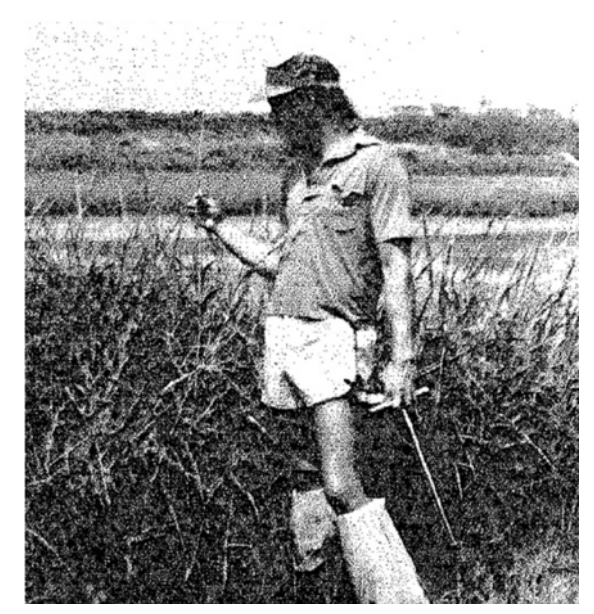

Horns of Silica

Facing growing disapproval from the academic world after this publication, Sea for Space retreated to a self-organized commune in the north of Iceland. There, they could host meetings with other climate activists and indulge in cult-like activities like beach cleaning, seed banking, and making symbiotic aquariums. From this northern retreat, they would periodically publish a research journal, the Symbiologist Bulletin, with articles and rants belonging to this so-called "New Science."

During their obsessive studies on salicornia, they had found one abnormal specimen of a plant covered with a shell resembling the silica formations of diatoms. Diatoms were ancient microscopic algae which built intricate geometric silica shells using a unique process of self-assembly. These miniature glass cathedrals were famously recorded by Ernst Haeckel. No one had ever recorded this shell-making process occurring elsewhere in the plant kingdom. This gave the "Horn of Silica" found by Sea for Space a mystical aura. "The lace-like shell forms intricate networks of glass around the stem akin to fungal rhizomes or silk cocoons" (Sea for Space 2068, 12), claims the article on the Horn of Silica from the Symbiologist Bulletin.

How might such an anomaly happen? And who cared for anomalies anyways? Heavily influenced by the writings of Lynn Margulis, the article defends the theory that salicornia and diatoms had developed a symbiotic relationship to survive the Ocean Dry-Up. The scenario illustrated with diagrams that thirsty colonies of microscopic diatoms agglutinated around the green stems of the plant and tapped into its xylems to suck up the water channeled from the roots. In exchange, the plant would use these silica shells scaffolding its skin as miniature solar panels to boost photosynthesis: I give you water, you give me sun and energy. With time, these mutualistic species would have formed a new symbiotic organism: a plant-algae-shell complex, a horn of glass and chlorophyll, which could adapt to wet or dry extreme conditions alike. In short, a species that would 
be indifferent to its environment being dry or submerged, and resilient to extreme variations in atmospheric composition.

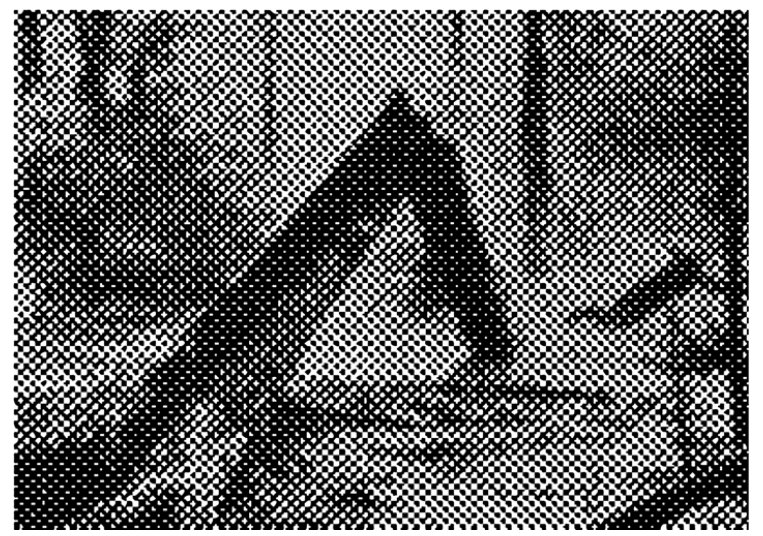

Using this discovery as a conceptual springboard, Sea for Space claimed that we might be on the brink of unearthing a new type of coral-like ecosystem that might tolerate traveling to other atmospheres. This revived the hope still shared by many for a possible interplanetary fauna and flora. The media coup created an unprecedented "space coral rush" attracting all sorts of opportunists and optimists to the ex-shores of Iceland. Space corals were a timely symbol for communities in search of new idols, and everyone wanted a piece of this new biological gold. The hopeful pilgrims made their way to north Iceland by plane, by car. Some even crossed the crystal deserts on foot. They built camps, erected stone cairns, and crowded the improvised hot dog stands, sharing maps and photos of their expeditions. In the evening, they rallied in an abandoned arthouse cinema to listen to Sea for Space speeches about future symbiosis.

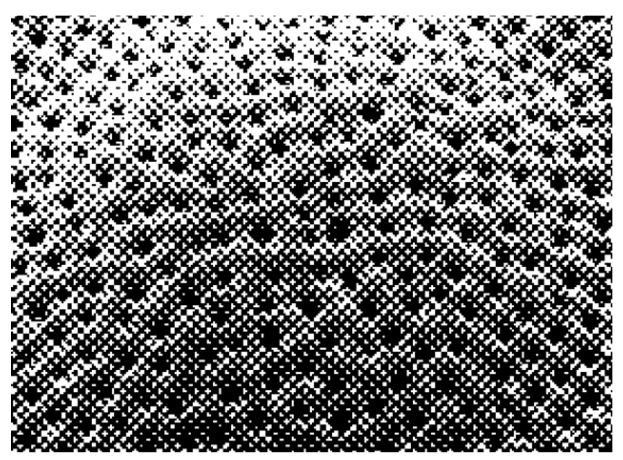


At dawn, they would be seen crawling on their knees, scouring the wastelands in search of a trace of the space coral.

Needless to say, no abundant "coral forest" was found. After a year of this frenzy, there was still only this one single shriveled fragment of Silica kept under protective glass. Horns of Silica became one amongst many other natural fetishes like petrified lightning or the last great auk crumbling in other dusty museum vitrines. The disappointed space coral lovers left one by one, leaving only a new layer of human waste on the Icelandic coasts. The now well-trodden concept of "ironic devolution" was crafted to describe this type of nostalgia induced by wishful biological mirages.

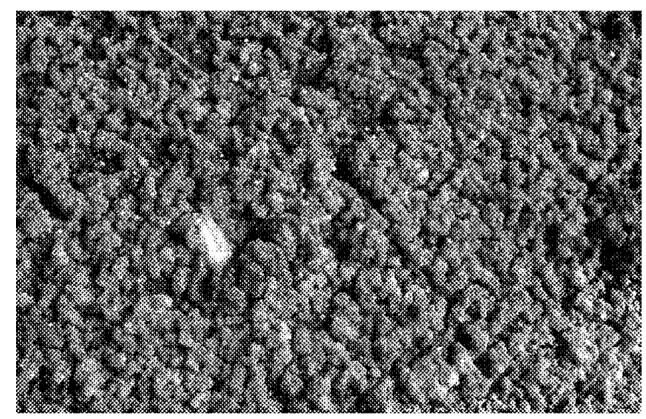

\section{New Shores}

It was around that time that, despite the liberties they had taken with dominant science, the Sea for Space researchers were recruited for a major astrogeological expedition to Mars. The mission's goal was to map the geomorphology of Oceanus Borealis for prospective mining of rare metals, a resource in growing demand. It was a bold role considering their eccentric profile. The argument was that their intimate knowledge of coastal geology would be a useful addition to a team of robots operating scanning drones. The expedition was funded by tech oligarch Sofia Brandenburg, who had made her fortune in commercial astrobotany. Brandenburg was famous for assembling teams of mavericks and interdisciplinary-minded lunatics for mercenary-but very lucrative-spatial ventures. She was too rich and too well connected to be criticized. On their side, the Sea for Space group was in dire need of cash after the recent space coral flop. They quickly abandoned their anticommercial principles and left the commune for the Mars Excavation Institute.

As it turned out, the megalomaniac Brandenburg had a very different agenda when reaching out to Sea for Space. Her "geological" mission was a cover designed to smuggle specimens of artificially preserved intertidal species and extremophile life forms to Mars, with the intention of mass- 
breeding them and selling them back on the Earth market. The traffic of exotic species between planets had become one of the most lucrative businesses. Each Sea for Space expedition to Oceanus Borealis could secretly shuttle a menagerie of pioneer plants (salicornia, dune grass, and more), containers filled with diatoms, urchins, sponges, coral species and whatever other hydrophytes Brandenburg's biologists had artificially kept alive in their intertidal aquariums.

For over a decade, this interplanetary traffic went unnoticed. Astrogeology was well regarded as a necessary activity for the industry since the ocean bed resources had been exhausted on Earth. The cover story was perfectly believable and packaged by an efficient marketing campaign. To their credit, the renegade Sea for Space researchers produced state-of-the-art geomorphological reports and maps of the shores of Oceanus Borealis in the early years of the mission. This kept their underground activities unsuspicious. Thanks to the unlimited resources provided by Brandenburg, they even contributed to the discipline of astrogeology by developing new mapping tools and techniques to model the dynamic formation of dunes on Mars, which I cannot resist including in this document. Unlike the coastal dunes of Earth, you will see that the Martian dunes have multiple slip faces, due to the hundreds of contradictory winds participating in the formations of the ventifacts. Our understanding of complex Polydunes is a legacy of this mission.

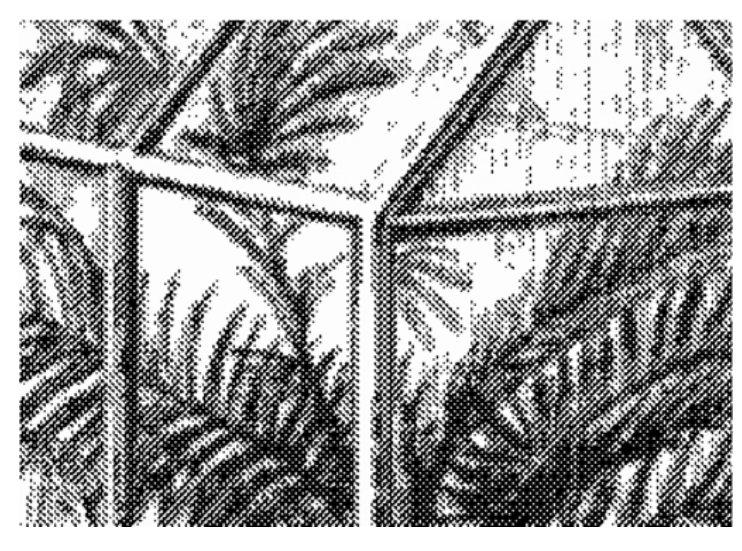

A more media-friendly side to this story was the public discussion about the decadent lifestyle that Sea for Space and Brandenburg had established on Mars. Rumors were spreading about a luxurious biosphere surrounded by a warm lagoon. Tabloids reported a forest ripe with tropical fruits growing in all seasons, complete with friendly birds of paradise revived from DNA samples flying around. At the origins of these popular stories was Mars by the Sea, a poetry book written by Frustula, one of the Sea for Space expatriates, which had leaked on the internet. Her lyrical texts and botanical descriptions were so vivid, colorful, and luscious that they sparked envy in the desert 
landscapes of Earth. Were these rumors another marketing trick orchestrated by Brandenburg to confuse public opinion and hide their illegal zoological activities?

Amid this moral controversy, the mission ended abruptly after the disappearance of several Sea for Space members in what was reported as a flash Martian sandstorm. Three researchers went missing without a trace. Following a scandal in the scientific community, the inquiry uncovered the illegal breeding activities but failed to find any satisfactory explanation for the tragedy. The other members of Sea for Space were repatriated to Earth and interrogated without much success. The group was dismantled and Brandenburg was heavily fined for misuse of the industrial research budget. In reality, she was blamed because the species breeding had no immediate taxable value. This astrobotanical "farce," as it was described by officials, had delayed more lucrative mining expeditions planned for Oceanus Borealis.

I have always found it puzzling, that after the survivors made it back to Earth, none of them claimed any fame for inventing the Polydunes Theory or revolutionizing geomorphological mapping techniques. They could easily have used this sordid story of failure to advance their career, write memoirs, or become media celebrities. Quite the opposite, the Sea for Space crew retired quietly, and everybody agreed on the total failure of the breeding experiment and mourned the loss of valuable researchers. Years passed before a mining mission came across the ruins of their illegal astrobotanical base. The lagoon had become a muddy pond filled with Martian regolith and the luxury biosphere had crumbled under the mighty sand winds. The images from these ruins reproduced in the report carried very little useful information. To find out what had exactly happened on the Martian shores, I decided to meet a Sea for Space survivor in person.

\section{Frustula}

I used my contacts in France to track down Frustula, the famous Sea for Space poet. Frustula had moved back to Brittany to dedicate herself to oyster farming and cosmological writing. Like the rest of the group, she insisted on being called by her code name long after the mission. Others had names such as Radiolaria, Amoeba, or Polyp. Frustula was the Latin name for the beautiful silica shells built by diatoms, the unicellular microalgae, which populated our oceans and had allegedly formed an association with salicornia in the Horn of Silica theory. The miniature glass architectures of diatom shells focused the distant sunlight underwater to increase photosynthesis. They were organic, chiseled glass solar panels with an infinite variation of morphology.

I had hoped the "human" Frustula could help me dissipate the fog I found myself in with the Oceanus Borealis enquiry. By that time, my head was filling up with strange visions of plant architects, shells morphing with leaves, and dunes shifting like water. I was still in the dark about the actual events on Mars, and how they could help explain the shimmering images we had received. The more data I gathered about this story, the more my certitudes were dissolving. During the week leading to my flight to Brittany to meet Frustula, I had some disturbing recurrent dreams where I was disappearing in quicksand. These were vivid nightmares, in which I was a different person every time, in a different place. However, the dreams always ended in the same 
way: my body was slowly engulfed by some sandy ooze, and I was as powerless as the tragic hero of Woman in the Dunes.

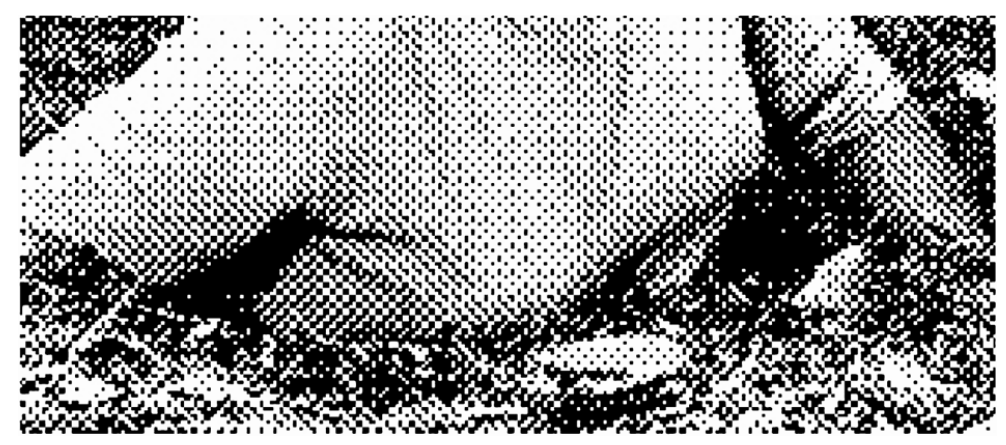

The long and dull flight to France over the Atlantic Crystal Desert was punctuated by these sandy visions. On arrival, I took the regional train to reach Frustula at her "waterless" oyster farm in Brittany. From the mugshots in the report, I was expecting to meet a bitter recluse. She would most probably retell the official story of her colleagues disappearing in a Martian sandstorm.

To my surprise, I was greeted at the station by a very joyful human, who looked much younger than eighty-four. Frustula belonged to that generation of Old Earth lovers who had adapted gracefully to disasters. Her coarse white hair seasoned by the ubiquitous salt framed an enigmatic face with fierce grey eyes. "What took you so long?" she asked. "We have a lot to talk about!"

We drove along the old Estran shore, scattered with ghost villages and shipwrecks. My host spoke constantly during the two-hour drive, occasionally pointing at local architectural remnants of the shell farming industry or at some geological formation: rusting oyster cages, empty clam tanks, and thousands of concrete pier columns covered with petrified mussels. Frustula explained that the shell industry had been doomed long before the Ocean Dry-Up when all the growers opted for artificial shell culture rather than water remediation. After this, all the funding for remediation science and industry was diverted to fuel the rush to excavate other planets. The knowledge gathered by several generations of shell farmers evaporated with the contaminated water. As we reached the surroundings of her oyster farm, her mood suddenly lifted: "Do you know why I have always loved oysters?" she asked mischievously, before answering her own riddle: "In an oyster, we are on Mars..."

Only now do I fully understand what Frustula meant. The atmospheric conditions inside a closed oyster shell are analogous to those in outer space: no sunlight, limited oxygen, heightened pressure. Extremophiles and pioneer species, which resist harsh environments and constant 
climatic changes, come from the sea, not from the continents. Intertidal organisms are the early life forms who colonized the Earth because their complex metabolism can sustain the extremes of outer space. This common-sense observation was the founding hypothesis of Sea for Space, and it had greatly inspired Brandenburg's dream. With hindsight, this makes the endless series of costly astrobotanical projects of growing cotton, lettuces, and other Earth-dependent plants in space with cumbersome technologies absurd. These were human-centered dreams, based on a colonial image of space as a mirror of our own planet. Despite seeing it as a "blue" marble, our enduring blindness to the oceans had rendered us equally blind to the real beauty and potentials of outer space. Only a handful of astrobotanists had ventured into growing algae in interplanetary travels. These experiments were very successful, but their findings were ignored by the spatio-agronomical lobbies modifying crops and seeds for interplanetary agriculture. And space-algae research was eventually abandoned.

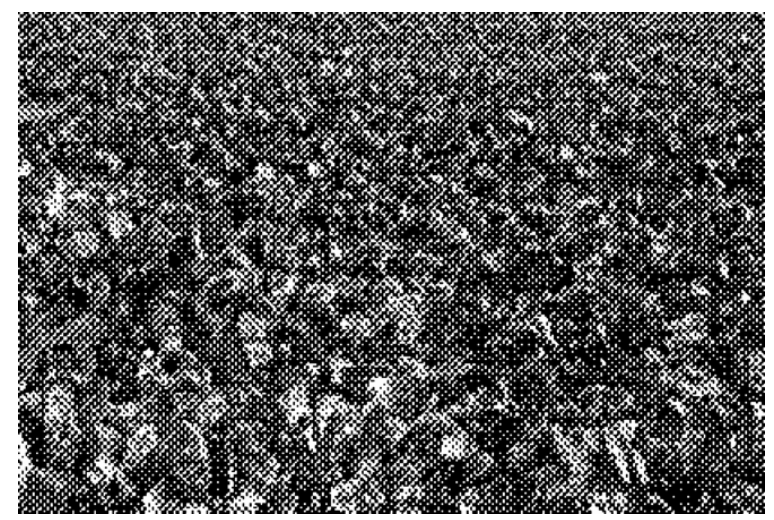

My day in the company of Frustula was filled with such revelations on the parallels between ocean biology and living conditions on Mars. I finally understood the limits of human-centered astrobotany, based on a colonial imaginary of space. I also started to realize that Sea for Space might have been underrated geniuses.

However, my visit to the waterless oyster nursery that evening was the most memorable experience. We had to tread barefoot for a few hundred meters on the beach in order not to crush any juvenile specimen that might have fallen from the baskets. As soon as the skin of my feet touched the damp, gelatinous sand, I was overtaken by an indescribable pleasure, which bordered on the erotic. A fine mist was hovering over the oyster beds, produced by a few homemade devices that used condensation and air to generate the water fog. I closed my eyes for a moment, letting the tiny droplets enter the pores of my face and refresh my bare ankles. For a short moment I imagined that when I would open them, the Atlantic Ocean would be scaling the horizon again. 
"Keep your eyes shut, and take this." Frustula had deposited in my hand half an oyster shell covered in seaweed and tiny barnacles. The shell had the coldness and weight of marble, although its curved relief gave it a soft, comforting feel. On the outside, I could feel with my fingertips a series of ridges spaced regularly from the central mount of the shell up until its sharp edges. I felt tears uncontrollably rolling down my cheeks. This was like touching a core of pure, stratified data.

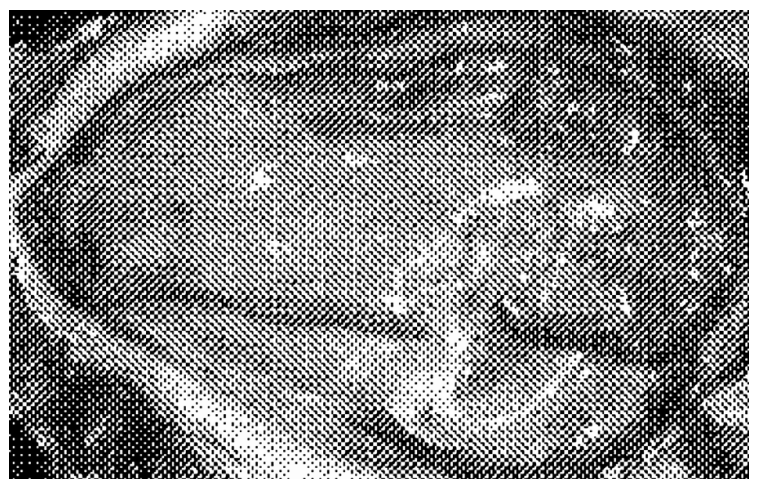

Reverse Trophic Cascade

Back at the farm, Frustula had laid out maps and her diaries from the Mars expedition on the kitchen table. "It is time," she said without waiting, "that our story is told. The story of Spacecoralia." With her permission, I started the sound recorder and sat back on the wooden chair in front of the papers and material fragments. What follows is the unedited account of the recording I made of Frustula that summer day in a remote corner of Brittany. I leave it up to you to believe these transcripts-but remember that this came from a discredited astrobotanist-turned-oyster farmer.

In the year leading to the disappearance of my colleagues, our artificial breeding of intertidal species had worked beyond our wildest hopes. We had created a miniature lagoon with the condensation from our greenhouse. Our small patches of genetically modified pioneer plants, which had taken five years to sprout and mature into adult individuals, were now growing at a fast rate all around the water's edge. The plants were deep blue, due to the filtered sunlight, which created variations in colours unlike any spectrum known on Earth. We had used CrisprCas to crossbreed hybrids of salicornia plants and diatoms. Yes! We synthesized our own Horns of Silica! We were mimicking the natural specimen we had found in northern Iceland. In this box, you can see some of the fossilized horns I smuggled back. They are so gorgeous, I miss waking up with them around me immensely. With these plant-diatom hybrids thriving and taking root, the first permanent 
Polydunes started to form on the edge of the water. A perfect spot to lie down and look at the stars. Inside the lagoon, Sofia wanted to experiment with a coral reef, which we named Spacecoralia. We used the proven methods for coral reef rehabilitation developed at Okinotorishima, the Japanese Coral Island (Nakamura et al 2011). The Japanese researchers had developed a sustainable system to produce adult corals of the Acropora tenuis species by assisting their hatching in tanks, in the same way that all the 'fake wild' salmon were produced on Earth back in the day. We had spread the larval settlements of polyps obtained with this same process or artificial hatching all around the lagoon bed. The colours they were taking cannot be explained in words! It was a constantly changing gradient of pinks and purples, sometimes fully translucent and sometimes reflective and shimmering. Because of the reduced air resistance and the absolute silence, we could hear these corals grow and move, like thousands of tiny mouths whispering to us that they were alive.

There was still some manual care work to carry out at this stage. To make sure that the balance of species was right, some of us had to dive in the lagoon every day and physically move some of the colonies by hand between cages. This was very delicate work, and with the sounds and texture of the space corals, a very immersive and visceral experience. This is when some strange things started to happen. The divers would stay longer and longer underwater, more than needed for their tasks. When they returned they started to talk about seeing other species that could not be there. One had seen Hyas, these spectacular sea worms; another swore he could see Gorgones...They all agreed that the species they were seeing were more like images or spectres. They were morphing into other life forms and dancing around the coral polyps as if emanating from the corals themselves. Some of us were joking that extinct species from Earth had come to haunt our artificial Martian paradise. But as scientifically minded people, we concluded on some light reflection, which-added to the fatigue of the divers - might have been taken for these moving life forms. Because of the tight schedule at this crucial time of the growth program, the divers were heavily medicated to be able to keep the same rhythm of work. But things got weirder. The following days the divers would often not speak for several hours after their dives. They would just wait by the lagoon, lying on the polydunes for their next shift back under, with a smile of beatitude.

We only had one team of divers, and they were obviously overworked. That evening, the emergency council gathered and we decided to suspend their manual handling of the space corals for a few days and to send our robotic submarine explorer to survey the underwater colonies. But the three divers refused to obey this decision and sunk back into the lagoon that same night...never to return. We also lost the submarine, which only emitted glitchy images before breaking down altogether. I found this notebook scribbled in the cabin of Amoeba, one of the divers. The last sentence reads: "I was alone, now we are a colony, a forest, a hive." 


\section{Works Cited}

Bradshaw, Nathaniel. 1842. On the Growth of Plants in Closely Glazed Cases. London: Ward.

Bratton, Benjamin. 2019. "Strelka 2020: New Programme Presentation." August 27. https://youtu.be/xZO_DNZanRQ

Buxton, Simon. 2006. The Shamanic Way of the Bee: Ancient Wisdom and Practices of the Bee Masters.

Rochetser: Inner Tradition Bears \& Company.

Chevalier, Auguste. 1922. "Les Salicornes et leur emploi dans l'alimentation : étude historique, botanique, économique." Journal de botanique Appliquée et d'Agriculture Coloniale 16: 697-785. https://doi.org/10.3406/jatba.1922.1484

Clément, Gilles. 2005. Manifeste du Tiers Paysage. Montreuil: Sujet-Objet.

Coccia, Emanuele, and Vinciane Despret. 2018. "Conversation: Emanuele Coccia - Vinciane Despret." Fondation Louis Vuitton, 10 June. https://www.youtube.com/watch?v=JDGNEJfxAPg

Epstein, Jean. 1929. Finnis Terrae (and other short films). France: Société Genérale de Films.

Evans, E. O. 1957. The Observer's Book of Geology. London and New York: Frederick Warne \& Co.

Low, S. 1887. The Vegetable Lamb of Tartary: A Curious Fable of the Cotton Plant, to Which Is Added a Sketch of the History of Cotton and the Cotton Trade. London: Marston, Searle \& Rivington.

Mabey, Richard. 2015. The Cabaret of Plants. London: Profile.

Nakamura, Ryota, et al. 2011. "Corals mass-cultured from eggs and transplanted as juveniles to their native, remote coral reef." Marine Ecology Progress Series 436: 161-168. https://doi.org/10.3354/meps09257

McHarg, Ian L. 1995. Design with Nature. New York: Wiley.

Painlevé, Jean. 2019. Science is Fiction, 23 Films. New York: The Criterion Collection.

Sea for Space. 2064. Making New Land. Reykjavik: Grandi Press.

Sea for Space. 2068. The Symbiologist Bulletin. Self-published.

Simons, Paul. 2016. "Samphire, tiny defender of sea-ravaged coastlines." Guardian, June 23. Accessed July 8, 2019. https://www.theguardian.com/science/2016/jun/23/plantwatch-samphire-sea-defence-coastal-marsherosion-glasswort

Tarkovsky, Andrei. 1972. Solaris. Moscow: Mosfilms.

Teshigahara, Hiroshi. 1964. The Woman in the Dunes. Tokyo: Teshigahara Productions.

Tournier, Michel. 1981. Gemini. London: Methuen.

Varda, Agnès. 2008. The Beaches of Agnès. Documentary film. Paris: Les Films du Losange.

Viles, Heather, and Tom Spencer. 1995. Coastal Problems. London: Arnold.

Zedler, Joy B. 1982. "The Ecology of Southern California Salt Marshes: A community profile." Washington, DC: US Department of the Interior, Fish and Wildlife Service, FWS/OBS-81/54. 


\section{Biography}

Thomas Pausz (b. Paris, 1978) is a critical designer and artist based in Reykjavik. In his interdisciplinary practice, Pausz stages real and fictional ecosystems to amplify the voice of non-human entities through careful work on media and narratives. In his entangled scenarios intersecting experimental science, ethics and contemporary design, Thomas Pausz offers a poetic space for renegotiating technological and biological hierarchies.

Recent exhibitions include Interspecies Futures (IF) at the Center for Book Arts, New York (2021); The Wildflower at Hafnarborg Museum, Iceland (2020); Creatures Made to Measure at Design Museum Gent (2019); Food Bigger than the Plate at the Victoria \& Albert Museum, London (2019); Species without Spaces at the Istanbul Design Biennale (2018); Making New Land at the Swamp Pavilion, Venice Architecture Biennale (2018); and Politics of Food: Markets and Mouvements at the Delfina Foundation, London (2016).

Website: www.pausz.org

(c) 2021 Thomas Pausz

cc) (ㅇ)

Except where otherwise noted, this work is licensed under a Creative Commons Attribution-

NonCommercial-ShareAlike 4.0 International License. 